Check for updates

Cite this: RSC Adv., 2018, 8, 12354

Received 1st December 2017 Accepted 22nd March 2018

DOI: 10.1039/c7ra12962a

rsc.li/rsc-advances

\section{DNA-induced synthesis of biomimetic enzyme for sensitive detection of superoxide anions released from live cell $\uparrow$}

\author{
Ailing Ding, Bin Wang, (D)* Xiaoqing Ma, Jianglin Diao, Jiushang Zheng, Jiucun Chen \\ and Changming $\mathrm{Li}$ (D)
}

In this work, we successfully fabricate a rapid, sensitive sensor for the detection of superoxide anions $\mathrm{O}_{2}{ }^{\cdot-}$ based on graphene/DNA/Mn $3\left(\mathrm{PO}_{4}\right)_{2}$ biomimetic enzyme. In the design, graphene is served as excellent carrier to improve the catalysis of $\mathrm{Mn}_{3}\left(\mathrm{PO}_{4}\right)_{2}$ nanoparticles; and DNA adsorbed on graphene acts as medium to assist the growth of $\mathrm{Mn}_{3}\left(\mathrm{PO}_{4}\right)_{2}$ on graphene. The fabricated graphene/DNA/Mn $3\left(\mathrm{PO}_{4}\right)_{2}$ composites exhibit excellently electrochemical activity, significantly decrease the response time and increase the sensitivity of the sensor towards $\mathrm{O}_{2}{ }^{--}$. The successful detection of $\mathrm{O}_{2}{ }^{--}$released from cancer cell demonstrated its potential applications in biology and medicine.

\section{Introduction}

Superoxide anions $\left(\mathrm{O}_{2}{ }^{--}\right)$are the primary type of reactive oxygen species (ROS). Under normal conditions, $\mathrm{O}_{2}{ }^{-}$is highly reactive and unstable and its metabolism is a rapid and spontaneous process. Overproduction of $\mathrm{O}_{2}{ }^{--}$can cause various disease, such as aging, asthma, ulcer disease, cancer, atherosclerosis, neurodegenerative diseases and other diseases. ${ }^{\mathbf{1 - 4}}$ Thus the detection of $\mathrm{O}_{2}{ }^{-}$is very important in various biological systems. Many methods have been developed for the detection of $\mathrm{O}_{2}{ }^{--}$including chemiluminescent, spectrophotometric, fluorometric, and electrochemical technique, etc. ${ }^{5-8}$ Among all these techniques, electrochemical method receives most attention due to its advantages of real-time assay, high sensitivity and selectivity. And most of the reported electrochemical methods for $\mathrm{O}_{2}{ }^{\cdot-}$ detection are based on enzyme catalysts such as cytochrome $c$ and superoxide dismutase (SOD)., ${ }^{2,-11}$ Though enzyme improves the assay performance of sensors, but its high cost and poor long-term stability increase difficulty of direct monitoring of $\mathrm{O}_{2}{ }^{-}$in biological samples. Therefore, it is a serious challenge for us to establish a fast, reliable, and sensitive non-enzyme approach for $\mathrm{O}_{2}{ }^{--}$monitoring in physiological and pathological processes.

As early as 1982, manganese was reported possessing an effective catalytic effect in vivo protection against superoxide toxicity. ${ }^{\mathbf{1 2}}$ In recent years, further study found that manganese phosphate $\left(\mathrm{Mn}_{3}\left(\mathrm{PO}_{4}\right)_{2}\right)$ has the ability to catalyze the

Institute for Clean Energy \& Advanced Materials, Faculty of Materials and Energy, Southwest University, Chongqing 400715, P. R. China. E-mail: bwang@swu.edu.cn; ecmli@swu.edu.cn

$\dagger$ Electronic supplementary information (ESI) available. See DOI: 10.1039/c7ra12962a dismutation of $\mathrm{O}_{2}{ }^{--}$compared with free $\mathrm{Mn}^{2+}$ ion that only stoichiometrically reacts with $\mathrm{O}_{2}{ }^{\cdot-} \cdot{ }^{13}$ Therefore $\mathrm{Mn}_{3}\left(\mathrm{PO}_{4}\right)_{2}$ is usually selected as a substitute for enzyme to detect $\mathrm{O}_{2} \cdot{ }^{\cdot-} \cdot{ }^{\mathbf{1 4}} \mathrm{MaO}$ et al. synthesize $\mathrm{SiO}_{2}-\mathrm{Mn}_{3}\left(\mathrm{PO}_{4}\right)_{2}$ nanoparticles derived from phytic acid and utilize for $\mathrm{O}_{2}{ }^{\cdot-}$ detection. ${ }^{15}$ Lan and co-workers deposit $\mathrm{Mn}_{3}\left(\mathrm{PO}_{4}\right)_{2}$ nanoparticles on carbon nanomaterials directly for the fabrication of $\mathrm{O}_{2}{ }^{\cdot-}$ sensor. ${ }^{16}$ These works verify the catalysis of Mn-superoxide dismutase mimics towards $\mathrm{O}_{2}{ }^{\cdot-}$. But the synthesis and property of nanoparticles need further study to improve the catalytic performance of sensor. In this work, we synthesize $\mathrm{Mn}_{3}\left(\mathrm{PO}_{4}\right)_{2}$ nanoparticles by DNA induction, which results in even dispersion and excellent catalytic activity towards $\mathrm{O}_{2}{ }^{\cdot-}$ disproportionation reaction.

Graphene is an increasingly important nanomaterials due to its excellent electronic conductivity, good stability, and promising catalytic performance in sensing. ${ }^{17-20}$ However, the two dimensional structure is easy to aggregate due to the singleatom-thickness, and hydrophobic aromatic structure. To solve this problem, we functionalize graphene with deoxyribonucleic acid (DNA) which can be adsorbed on graphene through $\pi-\pi$ stacking and don't destroy the intact structure of the carbon materials. ${ }^{20}$ Under the induction of ssDNA, $\mathrm{Mn}_{3}\left(\mathrm{PO}_{4}\right)_{2}$ nanoparticles was evenly deposited on the surface of graphene. The obtained graphene/DNA/ $\mathrm{Mn}_{3}\left(\mathrm{PO}_{4}\right)_{2}$ nanocomposites displayed significant biomimetic enzyme activity, rapid and sensitive response towards $\mathrm{O}_{2}{ }^{--}$. This approach holds a great promise for broad applications in biomedical research and clinical test.

\section{Experimental section}

\section{Chemicals and materials}

MCF-7 was bought from Cell bank of the representative culture preservation committee of the Chinese Academy of Sciences, 
China. Manganese sulfate $\left(\mathrm{MnSO}_{4}\right)$, potassium phosphate tribasic $\left(\mathrm{K}_{3} \mathrm{PO}_{4}\right)$ and Nafion were purchased from East Sichuan Chemical Industry (Group) Co., Ltd. (Chongqing, China) and used as received. Graphene was obtained from Sinocarbon Materials Technology Co., Ltd., China. Zymosan A (Zym, from Saccharomyces cerevisiae) SOD, DNA (low molecular weight extracted from salmon sperm), and potassium superoxide were purchased from Sigma-Aldrich and used without further purification. The $\mathrm{O}_{2}{ }^{-}$solutions were prepared by dissolving $\mathrm{KO}_{2}$ in PBS solution ( $\mathrm{pH} 7.0, \mathrm{~N}_{2}$ saturated). The concentration of $\mathrm{O}_{2}{ }^{--}$ was determined by the reduction of ferri cytochrome $c$ spectrophotometrically. ${ }^{21}$ All the other solutions were prepared using deionized water $(18 \mathrm{M} \Omega \mathrm{cm})$ and were degassed with high purity nitrogen before experiments. All electrochemical experiments were carried out at room temperature.

\section{Apparatus and instrumentations}

Scanning electron microscopy (SEM) images were taken by JSM6510LV, Japan. Field emission scanning electron microscopy (FESEM) images were taken by JSM-7800F, Japan. X-Ray diffraction (XRD) measurements were performed on a Shimadzu diffractometer (XRD-7000, Tokyo, Japan) operating in reflection mode with $\mathrm{Cu} \mathrm{K} \alpha$ radiation at a step size of 0.06 per second. The nanosheets of graphene/DNA/ $\mathrm{Mn}_{3}\left(\mathrm{PO}_{4}\right)_{2}$ were characterized by transmission electron microscopy (TEM, JEM2100F, Japan). Fourier transform infrared spectroscopy (FTIR) spectra were determined using a Thermo Nicolet 6700 FTIR spectrometer. Electrochemical performances were characterized using a CHI 660 system (Shanghai Chenhua, China). Graphene/DNA/ $\mathrm{Mn}_{3}\left(\mathrm{PO}_{4}\right)_{2}$ modified glassy carbon electrode (graphene/DNA/ $\mathrm{Mn}_{3}\left(\mathrm{PO}_{4}\right)_{2} / \mathrm{GCE}$ ) served as working electrodes, platinum sheet as counter electrode and $\mathrm{Ag} / \mathrm{AgCl}$ (in $3 \mathrm{M} \mathrm{KCl}$ ) acted as reference electrode. All $\mathrm{O}_{2}{ }^{-}$measurements were performed in $10 \mathrm{~mL} 0.01 \mathrm{M}$ PBS solution $(\mathrm{pH}=7.4)$.

\section{Synthesis of graphene/DNA/ $\mathrm{Mn}_{3}\left(\mathrm{PO}_{4}\right)_{2}$ nanosheets}

Graphene/DNA/ $\mathrm{Mn}_{3}\left(\mathrm{PO}_{4}\right)_{2}$ nanosheets were prepared by the previously reported method. ${ }^{22}$ Thirty milligrams of DNA was dissolved in $30 \mathrm{~mL}$ de-ionized water under stirring, after which the solution was annealed at $95{ }^{\circ} \mathrm{C}$ for $15 \mathrm{~min}$ to produce singlestranded DNA (ssDNA). Then the obtained ssDNA was mixed with $15 \mathrm{~mL}$ of $1 \mathrm{mg} \mathrm{mL}^{-1}$ graphene by mildly sonicated at $4{ }^{\circ} \mathrm{C}$ for $2 \mathrm{~h}$, thereafter filtration and washing were performed to remove excess ssDNA. Subsequently, the mixture was dispersed into $0.1 \mathrm{M} \mathrm{MnSO}_{4}$ solution, then $0.1 \mathrm{M} \mathrm{K}_{3} \mathrm{PO}_{4}$ solution were dropwisely added under stirring and kept at room temperature for $30 \mathrm{~min}$. Then graphene/DNA/ $\mathrm{Mn}_{3}\left(\mathrm{PO}_{4}\right)_{2}$ nanosheets were obtained by centrifugation at $8000 \mathrm{rpm}$ for 10 minutes and washing with deionized water for 3 times.

Glassy carbon electrode (GCE, $d=3 \mathrm{~mm}$ ) was polished with alumina slurry to a smooth and bright surface, washed by sonication for $30 \mathrm{~s}$ and dried under nitrogen. Then $5 \mu \mathrm{L}$ of the obtained graphene/DNA/ $\mathrm{Mn}_{3}\left(\mathrm{PO}_{4}\right)_{2}$ suspension was dropped on the electrode surface and dried at room temperature. Finally, $5 \%$ Nafion solution was coated to stabilize the fabricated electrode.

\section{In situ detection of $\mathrm{O}_{2}{ }^{--}$released form living cells}

MCF-7 cells were cultured in a humidified incubator (95\% air with $5 \% \mathrm{CO}_{2}$ ) at $37{ }^{\circ} \mathrm{C}$. The cells were cultured in Dulbecco's Modified Eagle's Medium (DMEM) (Cellgro, USA) supplemented with $1 \mathrm{~mol} \mathrm{~L}^{-1}$ glutamine, $50 \mathrm{U} \mathrm{mL}^{-1}$ penicillin/ streptomycin and $10 \%$ heat inactivated fetal bovine serum. ${ }^{\mathbf{1 4}}$ For the detection of $\mathrm{O}_{2}{ }^{--}$released from living cell, the incubation solution was removed and washed with PBS solution $(\mathrm{pH}$ 7.4) for three times. Before electrochemical measurement, zymosan (Zym) was added to motivate cells generation of $\mathrm{O}_{2}{ }^{\cdot-}$. Amperometric response was recorded by CHI-660B electrochemical station at applied potential of $700 \mathrm{mV}$ (versus $\mathrm{Hg}$ / $\mathrm{Hg}_{2} \mathrm{Cl}_{2}$ ).

\section{Results and discussion}

\section{Design of the modified graphene nanosheets}

Scheme 1 illustrates the synthesis of graphene/DNA/Mn $3\left(\mathrm{PO}_{4}\right)_{2}$ enzyme mimics by growth of $\mathrm{Mn}_{3}\left(\mathrm{PO}_{4}\right)_{2}$ on graphene under the induction of DNA. As we all know, single-strand DNA (ssDNA)

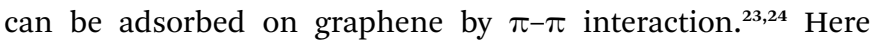
ssDNA was prepared by annealing double-strand DNA (dsDNA) and applied for graphene modification. In the presence of $\mathrm{Mn}^{2+}$, the divalent cations accumulate along the ssDNA backbone by the electrostatic interaction, which facilitate the formation of $\mathrm{Mn}_{3}\left(\mathrm{PO}_{4}\right)_{2}$ crystal nucleus on graphene and growth of $\mathrm{Mn}_{3}\left(\mathrm{PO}_{4}\right)_{2}$ nanoparticles upon the addition of negatively charged $\mathrm{PO}_{4}{ }^{3-}$ groups.

\section{Characterization of graphene/DNA/Mn $3\left(\mathrm{PO}_{4}\right)_{2}$ nanocomposites}

The morphology of the as-prepared graphene/DNA/Mn $3\left(\mathrm{PO}_{4}\right)_{2}$ nanosheets is characterized with scanning electron microscope (SEM). Fig. 1A and B shows the SEM images of graphene before and after adding $\mathrm{MnSO}_{4}$ and $\mathrm{K}_{3} \mathrm{PO}_{4}$, typical wrinkle of graphene can be clearly observed and no evident $\mathrm{Mn}_{3}\left(\mathrm{PO}_{4}\right)_{2}$ nanoparticles is found in Fig. 1B, suggesting that it is difficult to form $\mathrm{Mn}_{3}\left(\mathrm{PO}_{4}\right)_{2}$ nanoparticles on graphene surface without DNA. However, when ssDNA is modified on graphene (Fig. 1C and D), even-distributed $\mathrm{Mn}_{3}\left(\mathrm{PO}_{4}\right)_{2}$ nanoparticles can be evidently

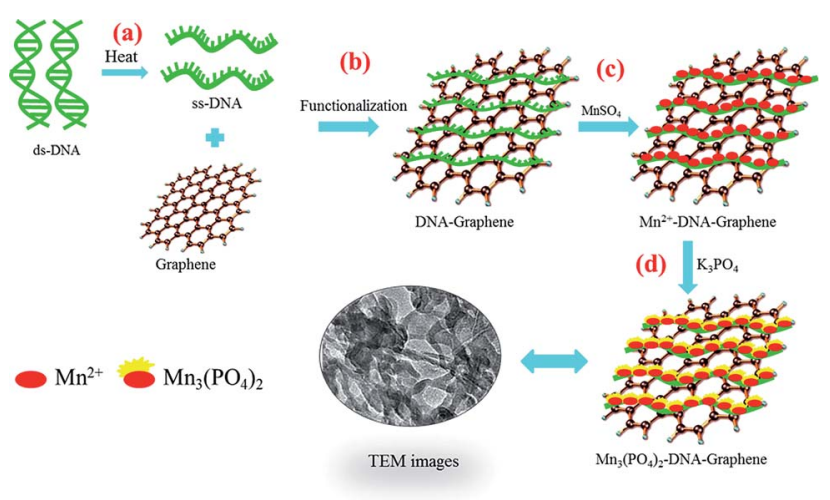

Scheme 1 Schematic illustration of the preparation procedure for the graphene/DNA/Mn $3\left(\mathrm{PO}_{4}\right)_{2}$. 


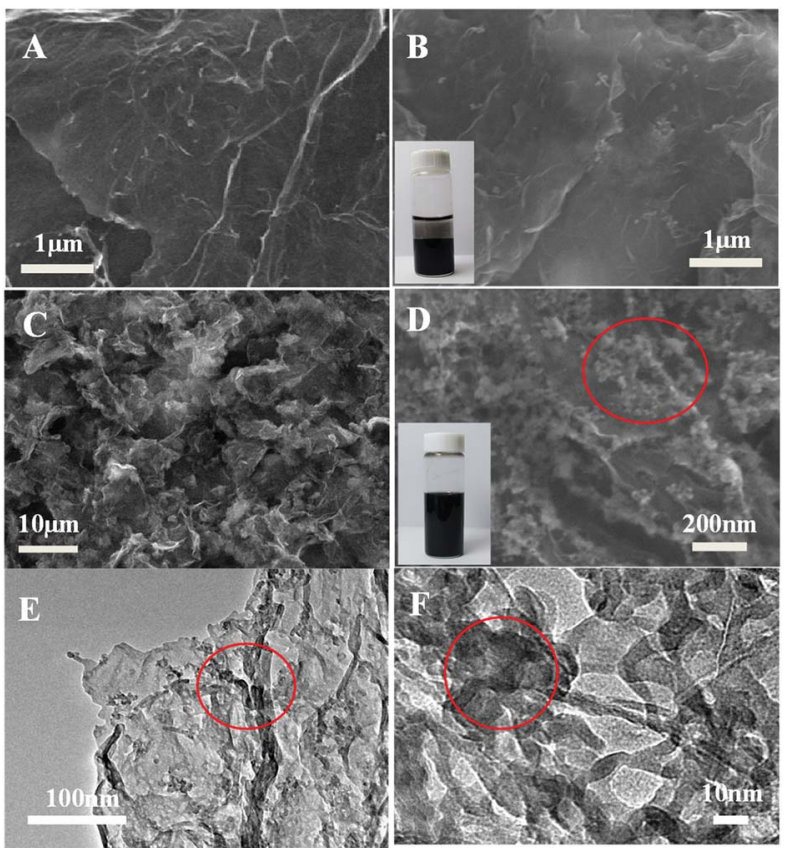

Fig. 1 (A) SEM images of pure graphene, (B): SEM images of graphene/ $\mathrm{Mn}_{3}\left(\mathrm{PO}_{4}\right)_{2}$ formed without DNA template, (C) and (D): SEM images of graphene/ $\mathrm{Mn}_{3}\left(\mathrm{PO}_{4}\right)_{2}$ formed with DNA template, (E) and (F): TEM images of graphene/ $\mathrm{Mn}_{3}\left(\mathrm{PO}_{4}\right)_{2}$ formed with DNA template. (The $\mathrm{Mn}_{3}\left(\mathrm{PO}_{4}\right)_{2}$ nanoparticles was labeled with red circle).

observed on the surface of graphene. The phenomena reveal the crucial role of ssDNA on the growth of $\mathrm{Mn}_{3}\left(\mathrm{PO}_{4}\right)_{2}$ on graphene. The TEM images in Fig. 1E and $\mathrm{F}$ display different morphology of $\mathrm{Mn}_{3}\left(\mathrm{PO}_{4}\right)_{2}$ nanoparticles due to the overlapping of particles. In order to verify the results, energy disperse spectrometer (EDS) was performed to explore chemical composition of the materials. The EDS results in Fig. S2 $\uparrow$ indicate that the major constituent elements of the wirelike nanostructure conclude $\mathrm{O}$ (68.7 at\%), P (12.1 at\%) and Mn (19.2 at\%), and the atomic ratio of $\mathrm{Mn}$ and $\mathrm{P}$ is close to $3: 2$, suggesting the existence of $\mathrm{Mn}_{3}\left(\mathrm{PO}_{4}\right)_{2}$ nanoparticles. The results further confirm the formation of well-defined thin-layer structure of the nanocomposites of $\mathrm{Mn}_{3}\left(\mathrm{PO}_{4}\right)_{2}$ nanoparticles on graphene surface.

Then FTIR spectra are determined to further verify the formation of graphene/DNA/ $\mathrm{Mn}_{3}\left(\mathrm{PO}_{4}\right)_{2}$ nanosheets. As shown in Fig. 2A, absorption peak at $1568.6 \mathrm{~cm}^{-1}$ can be assigned to the aliphatic carboxylic acid salts, the peaks at $996.0 \mathrm{~cm}^{-1}$ and
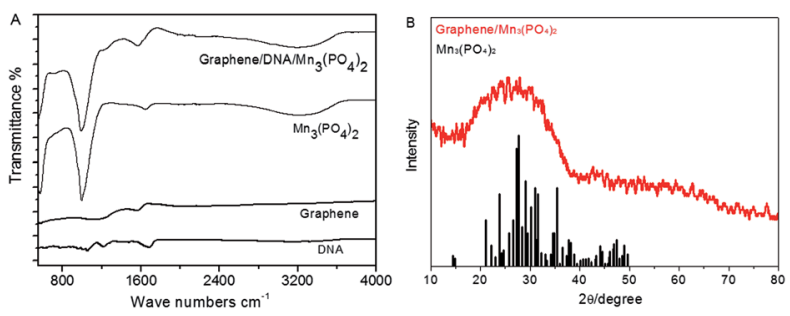

Fig. 2 (A): FTIR image of different materials; (B): X-ray diffraction pattern of graphene/DNA/Mn $3\left(\mathrm{PO}_{4}\right)_{2}$ nanosheets (red line) and the standard values of $\mathrm{Mn}_{3}\left(\mathrm{PO}_{4}\right)_{2}$ (black line).
$3196.3 \mathrm{~cm}^{-1}$ were attributed to inorganic phosphates. The results suggest that DNA and $\mathrm{Mn}_{3}\left(\mathrm{PO}_{4}\right)_{2}$ have been successfully modified on the graphene. In addition, the X-ray diffraction pattern (XRD) of graphene $/ \mathrm{Mn}_{3}\left(\mathrm{PO}_{4}\right)_{2}$ in Fig. 2B shows that the diffraction peak of the nanomaterials is at around $28.2^{\circ}$, which is consistent with the results of $\mathrm{Mn}_{3}\left(\mathrm{PO}_{4}\right)_{2}$. The results further confirm that $\mathrm{Mn}_{3}\left(\mathrm{PO}_{4}\right)_{2}$ nanoparticles are successfully modified on the surface of graphene. Then the zeta potential at various stages of the synthesis were measured to further characterize the formation of the nanocomposites. The results in Fig. S1 $\dagger$ indicate that the surface charge of graphene is about $-0.203 \mathrm{mV}$, which decreases to $-32.5 \mathrm{mV}$ as DNA was adsorbed on its surface due to the negative charge of DNA backbone. When $\mathrm{Mn}_{3}\left(\mathrm{PO}_{4}\right)_{2}$ was deposited, the zeta potential increase to $-15.6 \mathrm{mV}$, indicating the formation of graphene/DNA/ $\mathrm{Mn}_{3}\left(\mathrm{PO}_{4}\right)_{2}$ nanocomposites.

\section{Electrochemical properties of graphene/DNA/Mn $3\left(\mathrm{PO}_{4}\right)_{2}$ nanosheets}

Fig. 3 exhibits the electrochemical response of different materials in the absence and presence of $1.0 \mu \mathrm{M} \mathrm{O}_{2}{ }^{--}$and the mixture of $\mathrm{O}_{2}{ }^{-{ }^{-}}$and SOD (red column) in PBS. When graphene/ DNA/ $\mathrm{Mn}_{3}\left(\mathrm{PO}_{4}\right)_{2}$ nanosheets were modified on GCE, the obtained modified electrode displayed evident redox peaks around $0.7 \mathrm{~V}$ and $0.5 \mathrm{~V}$ in the absence of $\mathrm{O}_{2}{ }^{-{ }^{-}}$(as shown in Fig. S3†), which can be attributed to the electrochemical transformation between $\mathrm{Mn}^{2+}$ and $\mathrm{Mn}^{3+}$ species. However, no evident current response is observed when the mixture of $\mathrm{O}_{2}{ }^{\cdot-}$ and SOD is added, suggesting the current response attributed to the catalysis of the graphene/DNA $/ \mathrm{Mn}_{3}\left(\mathrm{PO}_{4}\right)_{2}$ nanosheets towards $\mathrm{O}_{2}{ }^{\cdot-}$. These results verify the biomimetic enzyme activity of graphene/ $\mathrm{DNA} / \mathrm{Mn}_{3}\left(\mathrm{PO}_{4}\right)_{2}$ to catalyze the dismutation of $\mathrm{O}_{2} \cdot{ }^{\cdot-} \cdot{ }^{25}$

In order to further study the electrochemical performance of graphene/DNA/ $\mathrm{Mn}_{3}\left(\mathrm{PO}_{4}\right)_{2}$ nanosheets, graphene/ $\mathrm{Mn}_{3}\left(\mathrm{PO}_{4}\right)_{2}$ were synthesized by direct depositing $\mathrm{Mn}_{3}\left(\mathrm{PO}_{4}\right)_{2}$ nanoparticles on graphene in the absence of DNA, DNA $/ \mathrm{Mn}_{3}\left(\mathrm{PO}_{4}\right)_{2}$

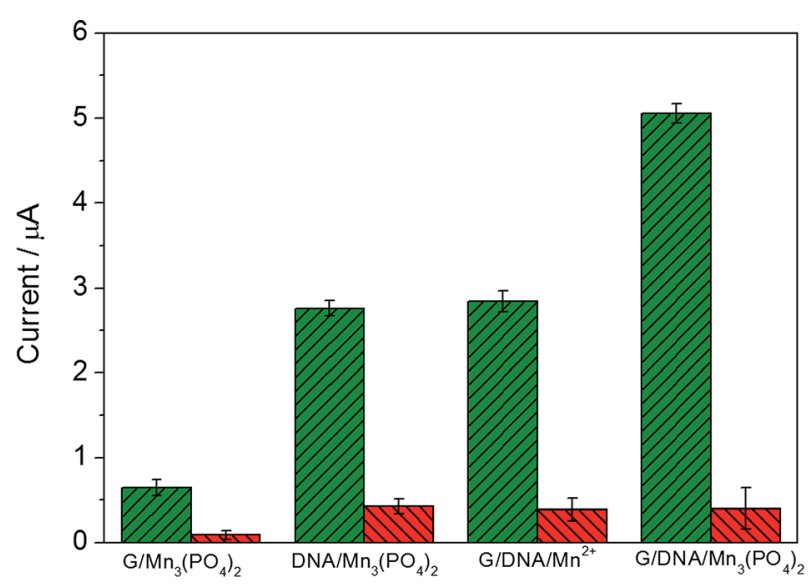

Fig. 3 Current response of graphene/ $/ \mathrm{Mn}_{3}\left(\mathrm{PO}_{4}\right)_{2} / \mathrm{GCE}, \mathrm{Mn}_{3}\left(\mathrm{PO}_{4}\right)_{2} /$ DNA/GCE, graphene/DNA/Mn ${ }^{2+} / \mathrm{GCE}$ and graphene/DNA/Mn $3\left(\mathrm{PO}_{4}\right)_{2} /$ GCE towards $\mathrm{O}_{2}{ }^{-{ }^{-}}$(green column) and the mixture of $\mathrm{O}_{2}{ }^{-}$and SOD (red column). The error bar was obtained from three measurements. 
nanoparticles were by prepared depositing $\mathrm{Mn}_{3}\left(\mathrm{PO}_{4}\right)_{2}$ on dsDNA template and graphene/DNA/ $\mathrm{Mn}^{2+}$ was synthesized by adsorbing DNA on graphene and subsequent depositing $\mathrm{Mn}^{2+}$ on DNA. Electrochemical performance of these materials were explored with electrodes modified with the above three nanomaterials (Fig. 3A-C). As shown in Fig. 3A, the electrode modified with graphene/ $\mathrm{Mn}_{3}\left(\mathrm{PO}_{4}\right)_{2}$ (graphene/ $\mathrm{Mn}_{3}\left(\mathrm{PO}_{4}\right)_{2} / \mathrm{GCE}$ ) possesses excellent electrical conductivity but the current response towards $\mathrm{O}_{2}{ }^{-}$is weak, verifying the good conductivity of graphene and poor modification of $\mathrm{Mn}_{3}\left(\mathrm{PO}_{4}\right)_{2}$ (Fig. 3A). Similarly, the electrodes modified with $\mathrm{Mn}_{3}\left(\mathrm{PO}_{4}\right)_{2} / \mathrm{DNA}$ and graphene/DNA $/ \mathrm{Mn}^{2+}$ display evident current response to $\mathrm{O}_{2}{ }^{\cdot-}$, but the current response is lower than that on graphene/DNA/ $\mathrm{Mn}_{3}\left(\mathrm{PO}_{4}\right)_{2} / \mathrm{GCE}$ (as shown in Fig. 3B and $\mathrm{C}$ ). The phenomena further prove that DNA plays important roles in the synthesis of graphene/DNA/ $\mathrm{Mn}_{3}\left(\mathrm{PO}_{4}\right)_{2}$ nanosheets. In addition, in comparison with the $\mathrm{Mn}_{3}\left(\mathrm{PO}_{4}\right)_{2} / \mathrm{DNA} / \mathrm{GCE}$ (Fig. 3B), we can see that the graphene/DNA/ $\mathrm{Mn}_{3}\left(\mathrm{PO}_{4}\right)_{2} / \mathrm{GCE}$ (Fig. 3D) displays stronger current signal due to the excellent conductivity of graphene.

The reason for DNA facilitating the growth of $\mathrm{Mn}_{3}\left(\mathrm{PO}_{4}\right)_{2}$ nanoparticles on graphene can be ascribed to two factors. First, the $\pi-\pi$ interaction between DNA and graphene induces ordered assembly of DNA on the surface of graphene, which is a critical factor to the synthesis of $\mathrm{Mn}_{3}\left(\mathrm{PO}_{4}\right)_{2}$ nanoparticles. Next, $\mathrm{Mn}^{2+}$ is adsorbed on DNA backbone to assist the nucleation of $\mathrm{Mn}_{3}\left(\mathrm{PO}_{4}\right)_{2}$ nanoparticles. In addition, in comparison with other conventional method, the DNA induced synthesis is easier to control the morphology and dispersion of products by adjusting temperature, $\mathrm{pH}$, or DNA concentration.

\section{Electrochemical response of $\mathrm{O}_{2}{ }^{\cdot-}$ at the present electrode}

Chronoamperometry is utilized to investigate the electrochemical response of graphene/DNA/ $\mathrm{Mn}_{3}\left(\mathrm{PO}_{4}\right)_{2} / \mathrm{GCE}$ towards $\mathrm{O}_{2}{ }^{-}$in $10 \mathrm{mM}$ PBS $(\mathrm{pH}=7.4)$. Fig. $4 \mathrm{~A}$ shows the stepwise current response of the present electrode with successive increasing $\mathrm{O}_{2}{ }^{\cdot-}$ concentration from $5 \mathrm{nM}$ to $400 \mathrm{nM}$. From the results in Fig. 4B we can see that the prepared sensor displays significant current response to the $\mathrm{O}_{2}{ }^{--}$concentrations in the range of $5 \mathrm{nM}$ to $400 \mathrm{nM}$ with a regression equation expressed as $I(\mu \mathrm{A})=0.00354 c(\mathrm{nM})+0.1504\left(R^{2}=0.999\right)$. The detection limit of the assay is calculated to be about $1.67 \mathrm{nM}(\mathrm{S} / \mathrm{N}=3)$ with a sensitivity of $3.54 \mu \mathrm{A} \mu \mathrm{M}^{-1}$, which is much more superior to most of previous reports. ${ }^{\mathbf{1 4 , 2 3 , 2 6 - 2 8}}$ The response time of the electrode to $\mathrm{O}_{2}{ }^{-}$is as short as $5 \mathrm{~s}$, which is an advantage for the detection of $\mathrm{O}_{2}{ }^{--}$due to its short lifetime. These results demonstrate that the present sensor may meet the requirement of $\mathrm{O}_{2}{ }^{--}$detection in normal physiological conditions. ${ }^{29}$

\section{The selectivity and stability of the present electrode}

The selectivity experience was carried out in the presence of various interfering species, such as $\mathrm{K}^{+}, \mathrm{Na}^{+}, \mathrm{Cl}^{-}, \mathrm{NO}_{3}{ }^{-}, \mathrm{SO}_{4}{ }^{2-}$, hydrogen peroxide $\left(\mathrm{H}_{2} \mathrm{O}_{2}\right)$, glucose (Glu), glutathione (GSH) uric acid (UA) and ascorbic acid (AA). Among these interferences, $\mathrm{H}_{2} \mathrm{O}_{2}$, UA and AA possess good electrochemical activity and perplex the detection of $\mathrm{O}_{2}{ }^{-}$due to their wide existence in biological systems. As shown in Fig. 5, in comparison to the
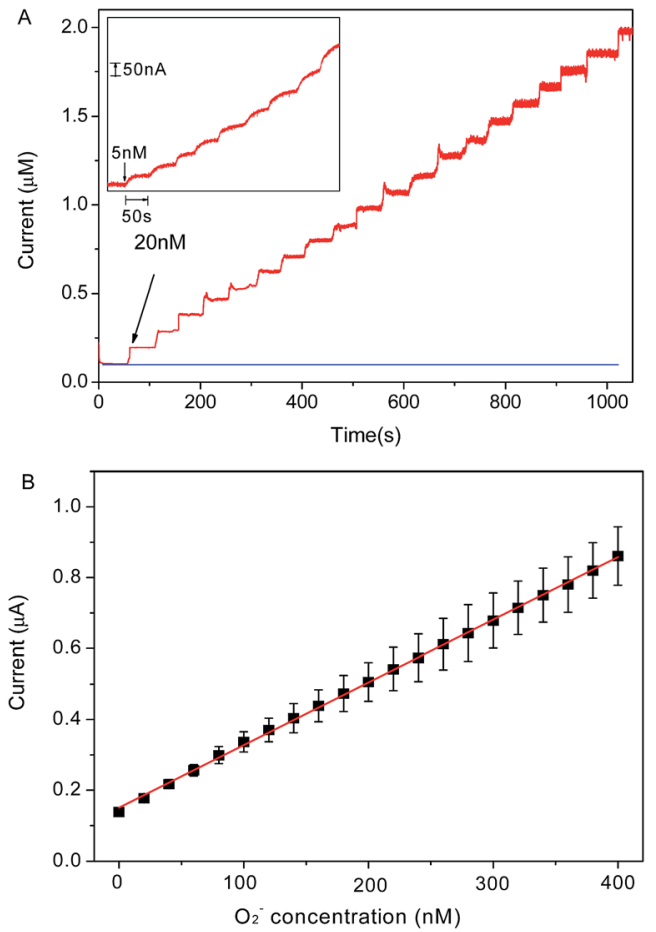

Fig. 4 (A): Typical amperometric responses of graphene/DNA/ $\mathrm{Mn}_{3}\left(\mathrm{PO}_{4}\right)_{2} / \mathrm{GCE}$ to successive additions of $20 \mathrm{nM} \mathrm{O}_{2}{ }^{\cdot-}$ and $5 \mathrm{nM} \mathrm{O}_{2}{ }^{\cdot-}$ (inset) at applied potentials of $700 \mathrm{mV}$ versus $\mathrm{Ag} / \mathrm{AgCl}$ in $10 \mathrm{mM}$ PBS $\left(\mathrm{pH}\right.$ 7.4); (B): linear plot for $\mathrm{O}_{2}{ }^{-}$detection.

electrochemical response of the as-present sensor to $100 \mathrm{nM}$ $\mathrm{O}_{2}{ }^{\cdot-}$, the presence of $10 \mu \mathrm{M} \mathrm{K}, \mathrm{Na}^{+}, \mathrm{Cl}^{-}, \mathrm{SO}_{4}{ }^{2-}, \mathrm{NO}_{3}{ }^{-}$, Glu. $\mathrm{GSH}, \mathrm{AA}, \mathrm{UA}$ and $\mathrm{H}_{2} \mathrm{O}_{2}$ did not cause any noticeable current
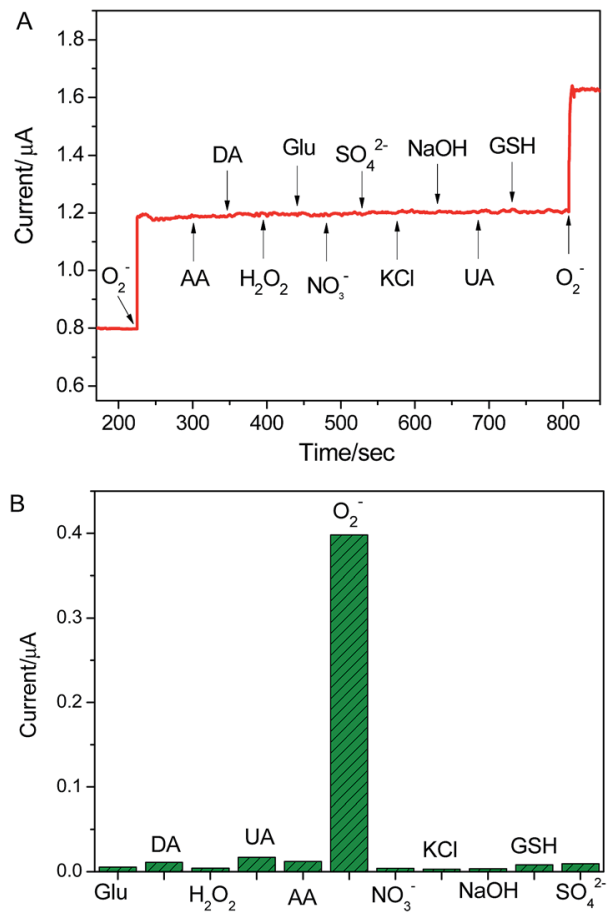

Fig. 5 The selectivity of graphene/DNA/Mn $3\left(\mathrm{PO}_{4}\right)_{2} / \mathrm{GCE}$ for the assaying of $\mathrm{O}_{2}{ }^{\cdot-}$ against the different interfering species. The response obtained upon the addition of $10 \mu \mathrm{M}$ interferes and $100 \mathrm{nM} \mathrm{O}_{2}{ }^{-}$. 

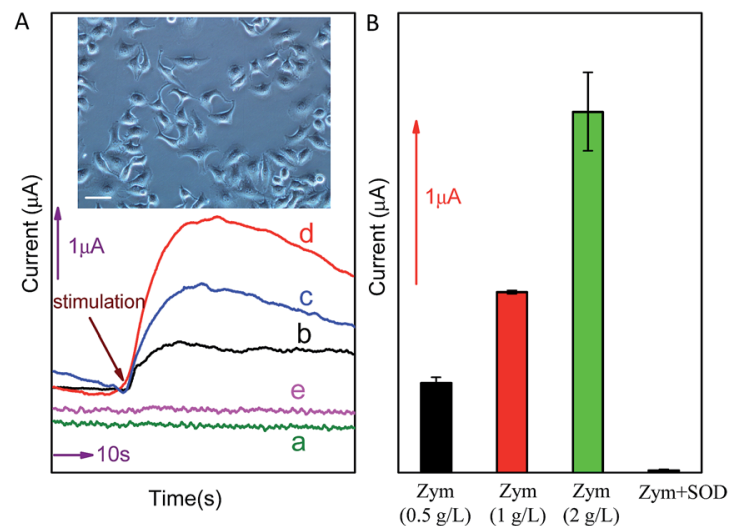

Fig. 6 (A): Electrochemical response of graphene/DNA/Mn $3\left(\mathrm{PO}_{4}\right)_{2} /$ GCE to $\mathrm{O}_{2} \cdot{ }^{-}$released by living MCF-7 cells (with the density of 105 $\mathrm{mL}^{-1}$ ) which stimulated by $0 \mathrm{~g} \mathrm{~L}^{-1}$ (a), $0.5 \mathrm{~g} \mathrm{~L}^{-1}$ (b), $1 \mathrm{~g} \mathrm{~L}^{-1}$ (c), $2 \mathrm{~g} \mathrm{~L}^{-1}$ (d)

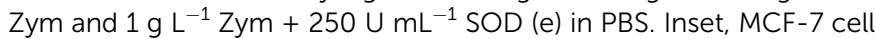
used in the determination (scale bar: $50 \mu \mathrm{m}$ ). (B): The histogram of (A)

response. The result suggests that the proposed sensor possesses excellent specificity to $\mathrm{O}_{2}{ }^{-}$detection in biological systems. In addition, the reproducibility and stability of the electrode were explored. The electrochemical response of the sensor was performed using five different electrodes fabricated at the same time, the standard derivations of current response was lower than $5.2 \%$. When the electrode was stored at $4{ }^{\circ} \mathrm{C}$ for one month, the current response towards $\mathrm{O}_{2}{ }^{--}$decrease $6.8 \%$ of original value (as shown in Fig. $\mathrm{S} 4 \dagger$ ). These results indicate that the excellent reproducibility and stability of the sensor.

\section{Detection of $\mathrm{O}_{2}{ }^{\cdot-}$ released from cancer cell}

In order to further investigate the potential application of the method in biological systems, the detection of $\mathrm{O}_{2}{ }^{-}$released from MCF-7 cells was performed at ambient temperature. As shown in Fig. 6, upon the addition of different concentration $\left(0.5 \mathrm{~g} \mathrm{~L}^{-1}, 1.0 \mathrm{~g} \mathrm{~L}^{-1}\right.$ or $2.0 \mathrm{~g} \mathrm{~L}^{-1}$ ) of zymosan (Zym, a drug was used to stimulate living cells to release $\mathrm{O}_{2}{ }^{-}$), a significant current response was observed (corresponding to $\mathrm{O}_{2}{ }^{-}$oxidation). According to the calibration curve in Fig. 5B, the concentration of $\mathrm{O}_{2}{ }^{--}$released from MCF-7 cells is calculated to be around $156.38 \mathrm{nM}, 315.71 \mathrm{nM}$ and $631.81 \mathrm{nM}$, respectively (the concentration of $\mathrm{O}_{2}{ }^{--}$released by per cell and total cells are calculated and listed on Table 1). The results indicate that

Table 1 Current response and the concentration of $\mathrm{O}_{2}{ }^{--}$released by MCF-7 cells (with the density of $10^{5} \mathrm{~mL}^{-1}$ ) under stimulation of different concentration of Zym

\begin{tabular}{llll}
\hline & $\begin{array}{l}\text { Response } \\
\text { current } \\
(\mu \mathrm{A})\end{array}$ & $\begin{array}{l}\text { Concentration of } \mathrm{O}_{2}{ }^{--} \\
\text {released by } \\
\text { cells }(\mathrm{nM})\end{array}$ & $\begin{array}{l}\mathrm{O}_{2}{ }^{--} \text {released } \\
\text { by per } \\
\text { cell }(\mathrm{pM})\end{array}$ \\
\hline Zym 0.5 g L & & \\
Zym 1 $\mathrm{g} \mathrm{L}^{-1}$ & 0.704 & 156.38 & 0.782 \\
Zym 2 $\mathrm{g} \mathrm{L}^{-1}$ & 1.268 & 315.71 & 1.579 \\
& 2.387 & 631.81 & 3.159
\end{tabular}

current response of $\mathrm{O}_{2}{ }^{--}$released form cancer cell under Zym stimulation is a concentration-dependent behavior. In addition, the results of control experiments (curve $d$ and $e$ shown in Fig. 6) indicate that no current was obtained upon the addition of either Zym or SOD-Zym mixture, confirming that the current responses were attributed to the drug-induced $\mathrm{O}_{2}{ }^{\cdot-}$ release from cells.

\section{Conclusions}

A novel $\mathrm{O}_{2}{ }^{\cdot-}$ biomimetic enzyme sensor based on graphene/ $\mathrm{DNA} / \mathrm{Mn}_{3}\left(\mathrm{PO}_{4}\right)_{2}$ nanosheets is successfully developed. The synthesized nanosheets display strong electrocatalytic activity towards $\mathrm{O}_{2}{ }^{--}$with high sensitivity, excellent selectivity and fast current response. The successful determination of $\mathrm{O}_{2}{ }^{--}$ released from cancer cells demonstrates the great potential for application in biological system. This work provides a new method for the fabrication of biomimetic enzyme sensor and a great promise for biosensing and biomedical application.

\section{Conflicts of interest}

There are no conflicts to declare

\section{Acknowledgements}

This work is financially supported by National Natural Science Foundation of China (21505108) and Technological and Developmental Grant (2015-09) from Beibei District Commission. The authors would also like to acknowledge the financial support of the Fundamental Research Funds (XDJK2016C132) for the Central Universities.

\section{Notes and references}

1 Y. W. Sheng, I. A. Abreu, D. E. Cabelli, M. J. Maroney, A. F. Miller, M. Teixeira and J. S. Valentine, Chem. Rev., 2014, 114, 3854.

2 Y. Tian, L. q. Mao and T. Ohsaka, Curr. Anal. Chem., 2006, 2, 51.

3 B. N. Ames, M. K. Shigenaga and T. M. Hagen, Proc. Natl. Acad. Sci. U. S. A., 1993, 90, 7915.

4 M. Ganesana, J. S. Erlichman and S. Andreescu, Free Radicals Biol. Med., 2012, 53, 2240.

5 Y. Ohara, T. E. Peterson and D. G. J. Harrison, J. Clin. Invest., 1993, 91, 2546.

6 J. L. Zweier, J. H. Flaherty and M. L. Weisfeldt, Proc. Natl. Acad. Sci. U. S. A., 1987, 84, 1404.

7 T. Ohyashiki, M. Nunomur and T. Katoh, Biochim. Biophys. Acta, 1999, 1421, 131.

8 Z. f. Deng, Q. Rui, X. Yin, H. Q. Liu and Y. Tian, Anal. Chem., 2008, 80, 5839.

9 V. Lvovich and A. Scheeline, Anal. Chem., 1997, 69, 454.

$10 \mathrm{~J}$. Chen, U. Wollenberger, F. Lisdat, B. X. Ge and F. W. Scheller, Sens. Actuators, B, 2000, 70, 115.

11 Z. Wang, D. Liu, H. Gu, A. Zhu, Y. Tian and G. Shi, Biosens. Bioelectron., 2013, 43, 101. 
12 F. S. Archibald and I. Fridovich, Arch. Biochem. Biophys., 1982, 214, 452.

13 K. Barnese, E. B. Gralla, D. E. Cabelli and J. S. Valentine, J. Am. Chem. Soc., 2008, 130, 4604.

14 F. X. Hu, Y. J. Kang, F. Du, L. Zhu, Y. H. Xue, T. Chen, L. M. Dai and C. M. Li, Adv. Funct. Mater., 2015, 25, 59245932.

15 X. Shen, Q. Wang, Y. Liu, W. Xue, L. Ma, S. Feng, M. Wan, F. Wang and C. Mao, Sci. Rep., 2016, 6, 28989-28998.

16 X. Cai, L. Shi, W. Sun, H. Zhao, H. Li, H. He and M. Lan, Biosens. Bioelectron., 2018, 102, 171-178.

17 J. F. Ping, Y. X. Wang, K. Fan, J. Wu and Y. B. Ying, Biosens. Bioelectron., 2011, 28, 204.

18 T. Kuila, S. Bose, P. Khanra, A. K. Mishra, N. H. Kim and J. H. Lee, Biosens. Bioelectron., 2011, 26, 4637.

19 B. Wang, Y. Wu, Y. Chen, B. Weng and C. Li, Sens. Actuators, $B, 2017,238,802-808$.

20 X. Zuo, S. He, D. Li, C. Peng, Q. Huang, S. Song and C. Fan, Langmuir, 2010, 26, 1936.
21 J. M. McCord and I. Fridovic, J. Biol. Chem., 1969, 244, 6049. 22 C. X. Guo, L. Y. Zhang, J. w. Miao, J. Zhang and C. M. Li, Adv. Energy Mater., 2013, 3, 167.

23 X. Ma, W. Hu, C. Guo, L. Yu, L. Gao, J. Xie and C. M. Li, Adv. Funct. Mater., 2014, 24, 5897.

24 H. Zhang, H. Huang, Z. Lin and X. Su, Anal. Bioanal. Chem., 2014, 406, 6925.

25 K. Barnese, E. B. Gralla, D. E. Cabelli and J. S. Valentine, J. Am. Chem. Soc., 2008, 130, 4604.

26 B. P. Crulhas, L. C. Recco, F. K. Delella and V. A. Pedrosa, Electroanalysis, 2017, 29, 1252.

27 X. Liu, X. Liu, H. Wei, G. Song, H. Guo and X. Lu, Sens. Actuators, B, 2017, 252, 503.

28 R. B. Sadeghian, S. Ostrovidov, J. Han, S. Salehi, B. Bahraminejad, H. Bae, M. Chen and A. Khademhosseini, ACS Sens., 2016, 1(7), 921.

29 Y. Luo, Y. Tian and Q. Rui, Chem. Commun., 2009, 3014. 